\title{
Evaluation of Staff Variable as Component of Quality Improvement for Maternal and Child Health Promotion in Baghdad City's Primary Health Care Centers
}

\author{
Dr. Naji Yasser Saadoon*
}

\author{
Dr. Mohammed F. Khalifa **
}

\begin{abstract}
Background and aim: Quality improvement consists of systematic and continuous actions that lead to measurable improvement in health care services including maternal and child health promotion and the health status of targeted patient groups like women and children. It is also recognized as a direct correlation between the level of improved health services and the desired health outcomes of individuals and population. The study aimed to evaluate the staff as component of quality improvement of maternal and child health promotion

Materials and method: A descriptive evaluation study is conducted on primary health care centers in Baghdad City from $10^{\text {th }}$ April 2012 to $20^{\text {th }}$ May 2013. A total of (22) primary health care centers. Data are collected through the utilization of the developed questionnaire and the interview technique as means of data collection. Data are analyzed through the application of descriptive statistical data analysis methods which includes the measurement of the frequencies, and percentages, and inferential statistical data analysis approach which includes the measurement of the multiple linear regressions and quality improvement.

Results: the study findings reveal that most of the health promotion staff have participated in some maternal and child health training and development courses, but they do not apply what has been learned, do not have access to books and publications, have to perform different tasks not health promotion only, do not acquire additional information, no testing the consumer's information, do not assign future appointments for planned and scheduled health promotion activities, and do not follow the consumers' benefits of previous health education, and decrease the number of the health promotion staff in the health promotion unit.

\section{Conclusion:}

There is increased demand and decreased supply of health promotion units at the primary health care centers. The aspect of staff has revealed that most of them has lacked practices and experiences relative to their task as providers of health promotion service to pregnant women as consumers of such services. Health promotion staff lack opportunities for training and development.
\end{abstract}

Keywords: staff, Quality Improvement, Maternal and Child Health, Health Promotion

\section{INTRODUCTION}

Studies on women's health indicate that most deaths of women around the world are related to pregnancy and childbirth (WHO, 2009). The primary goal of maternal and child health nursing care can be stated simply as the promotion and maintenance of optimal family health to ensure cycle of optimal childbearing and childrearing. Major philosophical assumptions about maternal and child nursing. Promoting health and disease prevention are important nursing roles because these protect the health of the next generation (Adele, 2009). Ideally, health promotion for the mother and infant should begin prior to conception. Attention to the health of the mother to be prior to conception has the potential to dramatically reduce infant mortality (death rate) and morbidity (Janice and Carolina, 2008). Quality improvement consists of systematic and continuous actions that lead to measurable improvement in health care services including maternal and child health promotion and the health status of targeted patient groups like women and children. It is also recognized as a direct correlation between the level of improved health services and the desired health outcomes of individuals and population (U.S. Department of Health and Human Services, 2011). In addition to staff, a key component of a well-functioning QI team is an effective infrastructure, such as, leadership, and policies and procedures to organize and facilitate the work of the team (Health Resources and Services Administration, 2011).

* Nurse Specialist / Al-Karkh General Hospital / Ministry of Health / Baghdad /njnj_3000@yahoo.com

** Professor / College of Nursing / University of Baghdad 
Nurses working with maternal and child health population require special qualities and education. It is recommended that nurses have the following qualifications (Allender et. a.l, 2005). In order to facilitate such process, nurses must provide people with relevant and appropriate information. Nurses are highly educated, experienced health professionals who are accessible through many settings. When nurses work within a health promotion model, every interaction with a client is an educational intervention. Nurses who are high level thinkers with exceptional skills, considerable ability to communicate, coordinate, and collaborate in order to deliver care (Hartford, 2013).

\section{MATERIALS AND METHOD}

A descriptive evaluation study is conducted on primary health care centers in Baghdad City. The study is carried out to evaluate the staff variable as a component of quality improvement of maternal and child health promotion from $10^{\text {th }}$ April 2012 through $20^{\text {th }}$ May 2013. A simple random sample of (41) staff variable who work in health promotion unit in primary health care center. Through an extensive review of relevant literature a questionnaire was constructed for the purpose of the study by the researcher according to the health promotion unit in the primary health care centers to measure the underlying concepts in the present study. The questionnaire is consisted of the following:

Part I: This part contains information about sociodemographic characteristics of staff at health promotion unit which includes age, gender, educational level, and years of employment in health promotion unit.

Part II: This part contains processes about training and development. (10) items.

Part III: This part contains processes about sustainability of health education. It is comprised of (three) items.

Data are collected through the utilization of the constructed questionnaire and the interview technique as means of data collection. Interviews are conducted with staff who are work in health promotion unit in primary health care centers.

Data are analyzed through the application of descriptive statistical data analysis methods, such as frequencies, and percentages and inferential statistical data analysis, such as multiple linear regression.

\section{RESULTS}

Table (1): Assessment of Staff Variable

\begin{tabular}{|c|c|c|c|}
\hline List & Items & Frequency & Percent \\
\hline \multirow{4}{*}{1} & Participation in training course about maternal and child health & & \\
\hline & No & 8 & $19.5 \%$ \\
\hline & Yes & 33 & $80.5 \%$ \\
\hline & Total & 41 & \\
\hline \multirow{4}{*}{2} & Participation in training course about teaching Methods & & \\
\hline & No & 39 & $95.1 \%$ \\
\hline & Yes & 2 & $4.9 \%$ \\
\hline & Total & 41 & $100 \%$ \\
\hline \multirow{4}{*}{3} & $\begin{array}{l}\text { Participation in training course about communication skills and } \\
\text { change of society behavior }\end{array}$ & & \\
\hline & No & 12 & $29.3 \%$ \\
\hline & Yes & 29 & $70.7 \%$ \\
\hline & Total & 41 & $100 \%$ \\
\hline \multirow{4}{*}{4} & $\begin{array}{l}\text { Participation in training course about providing a healthy } \\
\text { environment for mother and child }\end{array}$ & & \\
\hline & No & 31 & $75.6 \%$ \\
\hline & Yes & 10 & $24.4 \%$ \\
\hline & Total & 41 & $100 \%$ \\
\hline \multirow{4}{*}{5} & Participation in training course about the healthy lifestyle & & \\
\hline & No & 12 & $29.3 \%$ \\
\hline & Yes & 29 & $70.7 \%$ \\
\hline & Total & 41 & $100 \%$ \\
\hline \multirow{4}{*}{6} & Application of what has been learned & & \\
\hline & No & 10 & $24.4 \%$ \\
\hline & Yes & 31 & $75.6 \%$ \\
\hline & Total & 41 & $100 \%$ \\
\hline
\end{tabular}




\begin{tabular}{|c|c|c|c|}
\hline \multirow{4}{*}{7} & Books and publications are available in the primary health care & & \\
\hline & No & 35 & $85.4 \%$ \\
\hline & Yes & 6 & $14.6 \%$ \\
\hline & Total & 41 & $100 \%$ \\
\hline \multirow{4}{*}{8} & The training course has added new information to you & & \\
\hline & No & 6 & $14.6 \%$ \\
\hline & Yes & 35 & $85.4 \%$ \\
\hline & Total & 41 & $100 \%$ \\
\hline \multirow{4}{*}{9} & $\begin{array}{l}\text { Can you implement training course in the primary health care } \\
\text { center }\end{array}$ & & \\
\hline & No & 14 & $34.1 \%$ \\
\hline & Yes & 37 & $65.9 \%$ \\
\hline & Total & 41 & $100 \%$ \\
\hline \multirow{4}{*}{10} & Do you practice health promotion tasks only & & \\
\hline & No & 36 & $87.8 \%$ \\
\hline & Yes & 5 & $12.2 \%$ \\
\hline & Total & 41 & $100 \%$ \\
\hline \multirow{4}{*}{11} & Testing the consumers after health education & & \\
\hline & No & 14 & $34.1 \%$ \\
\hline & Yes & 27 & $65.9 \%$ \\
\hline & Total & 41 & $100 \%$ \\
\hline \multirow{4}{*}{12} & $\begin{array}{l}\text { The consumer is given a future appointment for a planned and } \\
\text { scheduled health promotion activities }\end{array}$ & & \\
\hline & No & 37 & $90.2 \%$ \\
\hline & Yes & 4 & $9.8 \%$ \\
\hline & Total & 41 & $100 \%$ \\
\hline \multirow{4}{*}{13} & $\begin{array}{l}\text { The consumers are followed about the degree of benefit of } \\
\text { previous health education }\end{array}$ & & \\
\hline & No & 36 & $87.8 \%$ \\
\hline & Yes & 5 & $12.2 \%$ \\
\hline & Total & 41 & $100 \%$ \\
\hline
\end{tabular}

Table (2): Comparison between Staff Relative to Demand and Supply of Health Promotion Units

\begin{tabular}{|l|c|c|c|c|}
\hline Health Directorate & Demand & Supply & Comparison & Percentage of Shortage \\
\hline Al-Russafa & 49 & 25 & -24 & $48.9 \%$ \\
\hline Al-Karkh & 38 & 19 & -19 & $50 \%$ \\
\hline
\end{tabular}

Table (3): Multiple Linear Regression for the Relationship between Quality Improvement and the Aspect of Staff

\begin{tabular}{|c|l|c|c|c|c|}
\hline \multirow{2}{*}{ List } & \multirow{2}{*}{ Items } & \multicolumn{2}{|c|}{$\begin{array}{c}\text { Unstandardized } \\
\text { Coefficients }\end{array}$} & $\begin{array}{c}\text { Standardized } \\
\text { Coefficients }\end{array}$ & \multirow{2}{*}{ Sig. } \\
\cline { 3 - 5 } & & $\mathbf{B}$ & Std. Error & Beta & \\
\hline 1 & Gender & 1.107 & .298 & .140 & .001 \\
\hline 2 & Age & .864 & .155 & .193 & .000 \\
\hline 3 & Level of education & 1.044 & .165 & .172 & .000 \\
\hline 4 & Number of employment years & 1.324 & .157 & .335 & .000 \\
\hline 5 & Participate in training course (MCH) & 1.160 & .273 & .118 & .000 \\
\hline 6 & $\begin{array}{l}\text { Participate in training course about teaching } \\
\text { methods }\end{array}$ & .242 & .591 & .013 & .686 \\
\hline 7 & $\begin{array}{l}\text { Participate in training course about } \\
\text { communication skills }\end{array}$ & 1.312 & .370 & .153 & .002 \\
\hline 8 & $\begin{array}{l}\text { Participate in training course about a healthy } \\
\text { environment }\end{array}$ & 1.037 & .330 & .114 & .005 \\
\hline 9 & $\begin{array}{l}\text { Participate in training course about the healthy } \\
\text { lifestyle }\end{array}$ & .827 & .305 & .096 & .012 \\
\hline
\end{tabular}




\begin{tabular}{|c|l|c|c|c|c|}
\hline 10 & Apply what have you learned & 1.161 & .294 & .128 & .001 \\
\hline 11 & Books and publications are available & 1.260 & .326 & .114 & .001 \\
\hline 12 & The training course you have added information & .831 & .362 & .075 & .031 \\
\hline 13 & Implement training course & .771 & .287 & .094 & .013 \\
\hline 14 & Health promotion tasks only & 1.450 & .403 & .122 & .002 \\
\hline 15 & Tests after education & .787 & .288 & .096 & .012 \\
\hline 16 & $\begin{array}{l}\text { Future appointment for a planned and scheduled } \\
\text { health promotion activities }\end{array}$ & 1.404 & .738 & .107 & .070 \\
\hline 17 & $\begin{array}{l}\text { Followed about the degree of benefit previous } \\
\text { education }\end{array}$ & .446 & .681 & .037 & .519 \\
\hline
\end{tabular}

Dependent Variable: Quality Improvement

Table (4): Determination of Quality Improvement for Staff Variable

\begin{tabular}{|c|c|c|c|c|c|c|c|c|}
\hline \multirow{3}{*}{ Staff } & \multicolumn{2}{|c|}{$\begin{array}{c}\text { Poor } \\
19-24\end{array}$} & \multicolumn{2}{|c|}{$\begin{array}{c}\text { Fair } \\
\text { 25-30 }\end{array}$} & \multicolumn{2}{|c|}{$\begin{array}{c}\text { Good } \\
31-36\end{array}$} & \multicolumn{2}{|c|}{ Total } \\
\hline & $\mathrm{f}$ & $\%$ & $\mathrm{~F}$ & $\%$ & $\mathrm{f}$ & $\%$ & $\mathrm{f}$ & $\%$ \\
\hline & 10 & $24.39 \%$ & 24 & $58.53 \%$ & 7 & $17.07 \%$ & 41 & $100 \%$ \\
\hline
\end{tabular}

f: Frequency \%: Percentage

\section{DISCUSSION}

The findings of the study reveal that most of the staff is young females, Diploma Degree graduates, has less than five years of work in health promotion units, do not participate in any means of training, do not apply what has been learned. Such findings present a fact that the majority of the staff has lacked practice and experience relative to their task as providers of health promotion service to pregnant women. (Table 1and 3), do not have access to books and publications, have to perform different tasks not health promotion only, do not acquire additional information, do not test the consumers, do not assign future appointments for planned and scheduled health promotion activities, and do not follow the consumers' benefits of previous health education (Table 1 and 3). Regarding health promotion staff supply and demand, the study findings depicted that Al-Karkh District has experienced more shortage of staff at the health promotion units in primary health care centers than those in Al-Russafa District (Table 2). This result may be due to lack in staffing or performing job analysis for the staff. Accurate knowledge of the characteristics of the health labor force that can affect health care production is of critical importance to health planners and policymakers. The other study uses health facility survey date to examine characteristics of the primary health care labor. The characteristics examined are those that are to affect service provision, including distribution, demographic characteristics, and experience and in-service training providers. Accurate knowledge of the health labor force is of critical importance to health planners and policymakers worldwide. This is because careful, informed decision-making is necessary to achieve the right balance between the supply of labor and a population's health demands. Insufficient or inaccurate information about the health labor force. Knowledge of the labor force is also important because labor is one of the key inputs into health systems. The world health organization has stated that the health labor force is the most important of the health system's inputs', due not only to the dependence on the workforce to provide quality services, but also the costs involved with training employing and managing the necessary supply of labor to achieve good health care outcomes. The quantity of available health care providers is an important aspect of the labor force. The stock of providers often assessed in relation to population size, typically by the number of physicians or nurses available per capita. Characteristics of the health labor force that could potentially affect the production of health care, such as inadequate distributions of gender, educational levels, training and experience among health care providers (Barden and Tsui, 2006).

Deficits in staff knowledge were an ongoing challenge. Staff had limited time to 
acquire necessary expertise and then moved on as their skills developed (Sorfenyoh et. a.l, 2012).

The effective training of health care providers in general, in skills to manage critical moments and emergency situations in $(\mathrm{MCH})$ care, is relevant to the improvement of professional practice and to the reduction of maternal and neonatal mortality and morbidity. The knowledge and skills that should be targeted by the training program are evidence-based basic essential obstetric care, management of acute obstetric complications, essential newborn care and neonatal resuscitation, as most causes of maternal and perinatal deaths are related to these circumstances. Training programs can be conducted as interactive workshops for relatively small groups, using dummies, simulation models and exercise. These training can also include plans and strategies to implement the recommended forms of care in the health care setting, including providing appropriate materials (Altabe et. al., 2008). Improve of educational level within disciplines has largely come from the different professional group, working to improve provision, support and access to ongoing education and development (Sue, 2009). Communication skills are as important as vital needs. Health care professionals have to be aware of their own communication practices and need to undergo periodic appraisal of them. Training programs in communication skills are unfortunately not part of our academic curriculum. Good communication skills are essential for high quality, effective, and safe medical practice. These skills are used for information gathering, diagnosis, treatment, and patient education. Communication skills can be effectively trained but are best achieved through reviewing our own style of communication (Pallat, 2011).

Concerning the aspect of staff, its indicators have significant impact upon the quality improvement except those of staff variables (Table 4). Sustainable health promotion actions are those that can maintain their benefits for communities and populations beyond their initial stage of implementation. Sustainable action can continue to be delivered within the limits of natural resources, and participation by stakeholders (WHO, 2009).

\section{CONCLUSION}

There is increased demand and decreased supply of health promotion units at the primary health care centers. The aspect of staff has revealed that most of them has lacked practices and experiences relative to their task as providers of health promotion service to pregnant women as consumers of such services. Health promotion staff lack opportunities for training and development.

\section{RECOMMENDATIONS}

Upon the previously stated interpretation of findings, the study can recommend that Staff has to be presented with better education and opportunities for well-structured training courses in the area of health promotion. In addition, adequate number of qualified health promotion staff. Finally, health promotion staff must be provided with opportunities for training and development.

\section{REFERENCES}

Adele, P. (2009). Maternal and Child Health Nursing Care of the Childbearing and Childrearing Family. $\left(6^{\text {th }}\right.$ ed.). Walters Kluwer Health. p 4.

Allender, A., Rector, C., and Kristine, D. (2005). Community Health Nursing: Promoting and Protecting the Public's Health. ( $7^{\text {th }}$ ed.). Philadelphia: Lippincott Williams and Wilkins.

Altabe, F., Berge, E., Luisa, M., Gibbons, L., Ciapponi, A., and Aleman, A. (2008). Strategies for Improving the Quality of Health Care in Maternal and Child Health in Low and Middle Income Countries. Pediatric Epidemiology. 22 (1). p.p. 42-60.

Barden, J., and Tsui, A. (2006). Imbalances in the Health Labor Force. Health Policy and Planning. 21(2). p.p. 80-90.

Hartford, J. (2013). The Role of the Nurse in Health Promotion. Retrieved from http://www.hospitalnews.com/ on Oct. 2010.

Health Resources and Services Administration (HRSA). (2011). U. S. Department of Health and Health Services. p.p. 2-5.

Janice, A., and Carolina, G. (2008). Health Promotion in Nursing. ( $2^{\text {nd }}$ ed.). United State of America: Cengage Learning. p.p.19-26.

Pallat, J. (2011). Training Programs in Communication Skills for Health Care Professionals and Volunteers. Indian Journal of Palliative care. 17(1). p.p. 512-513.

U.S. Department of Health and Human Services (USDHHS). (2011). Quality Improvement.

Sorfenyoh, E., Ivester, T., Engmann, C., and Owen, M. (2012). Advancing Obstetric and Neonatal Care in a Regional Hospital in Ghana. Gynecology and Obstetrics, 116 (3). p.p. $17-22$.

Sue, P. (2009). Professional Development in Primary Care. p.p. 1-6. Retrieved from: www.The Free Library. Com/ on 12.10.2009.

World Health Organization (WHO). (2009). Maternal Health. Geneva. 